\section{A PRELIMINARY CHECKLIST OF BUTTERFLIES RECORDED FROM JEYPORE-DEHING FOREST, EASTERN ASSAM, INDIA}

\section{Monsoon Jyoti Gogoi}

Bokakhat East Dagaon, Golaghat District, Assam 785612, India monsoonjyoti@gmail.com

Jeypore Reserve Forest (JRF) is one of the few remaining continuous stretches of woodland left in upper Assam. The forest lies just inside the south bank of the Brahmaputra River Basin, which is the barrier for many dispersal limited Malayan flora and fauna. The reserve forest further lies in the foothills of PatkaiBum hill ranges of Arunachal Pradesh which is likely to influence the bio-geographic pattern of many Malayan butterflies in northeastern India. Despite the biogeographic significance of the area, the area remains poorly documented in terms of butterfly community and hence data deficient. Doherty (1889) described Blue Quaker Pithecops fulgens and Yellow-vein Lancer Pyroneura margherita from nearby Margherita. But, nothing was known of the butterfly community in JRF. The present study was therefore taken with an objective of providing a baseline data of the butterfly community in JRF.

Study area: Jeypore Reserve Forest (JRF) (27006' $\left.-27^{0} 16^{\prime} \mathrm{N} \& 95^{\circ} 21^{\prime}-95^{\circ} 29^{\prime}\right)$, with a total area of $10,876 \mathrm{~km}^{2}$ is located in Dibrugarh District of Upper Assam, adjoining Arunachal Pradesh. The reserve forest falls under the Jeypore-Dehing Landscape of Assam Valley semi-evergreen rainforest (Champion \& Seth 1968) and is one of the last remaining large tracts of lowland tropical forests left in Upper Assam (Image 1). JRF falls under the Eastern Himalayan biodiversity hotspot. The reserve forest lies in the foothills of the Patkai range and the terrain is characterized by the undulating hill ranges of Arunachal Pradesh meeting the plains of the



ISSN

Online 0974-7907 Print 0974-7893

\section{OPEN ACCESS} Assam Valley. The reserve has a passage through it, leading to Deomali and Khonsa in Arunachal Pradesh (Image 2). The river Burhi-Dehing flows through the northern boundary of the reserve forest and Dilli River flowing through Namrup lying at an elevation of $124 \mathrm{~m}$ is the southern boundary of the reserve. The vegetation is characterized by Dipterocarpus marcocarpus, Messua ferrea and Vatica lanceafolia from the top canopy to the middle. The ground floor is dominated by Saprosma ternatum, Livistonia jenkiansiana and Calamus erectus etc. Bamboo species of Dandrocalamus hamiltonii and Pseudostachyum polymorphum are present in most patches of the forest.

Materials and methods: JRF was surveyed in different seasons, February (2010), May (2010), November (2010) and September-October (2011). The survey was done on different forest trails and hill streams regularly between 10.00-15.00 hr (Image 3). Butterfly species were identified using the identification keys of Evans (1932), Talbot (1947), and photographic guides of Kehimkar (2008) and Haribal (1992).

Notes on selected species:

White Punch Dodona longicaudata De Nicéville (Image 4): One individual was encountered in February of around $150 \mathrm{~m}$. The species has also been photographed and sighted recently from Namdapha and

DOI: http://dx.doi.org/10.11609/JoTT.03022.3684-96 | ZooBank: urn:Isid:zoobank.org:pub:3FB58B80-C636-418F-B3FD-307245A84375

Manuscript details: Ms \# 03022 | Received 25 November 2011 | Final received 11 December 2012 | Finally accepted 15 December 2012

Citation: Gogoi, M.J. (2013). A preliminary checklist of butterflies recorded from Jeypore-Dehing forest, eastern Assam, India. Journal of Threatened Taxa 5(2): 3684-3696; doi:10.11609/JoTT.03022.3684-96.

Copyright: (c) Gogoi 2013. Creative Commons Attribution 3.0 Unported License. JoTT allows unrestricted use of this article in any medium, reproduction and distribution by providing adequate credit to the authors and the source of publication.

Funding: Some amount of funding was provided by Assam Forest Department as a part of Jeypore Biodiversity Coffee Table Book, while the fund was selffinanced to complete the checklist.

Competing Interest: None.

Acknowledgements: The author thanks Kashmira Kakati and A. Christy Williams for makings the field arrangements and accommodation during the survey and providing the map for my report. The author would also like to thank the local guides, Lakhindra, Dilip, Khageswar and orchid specialist Khyanjeet Gogoi for assisting on the field. The author also thanks James Young for providing the available literatures. 




Image 1.Google map of Jeypore-Dehing landscape, Upper Assam, Coutrsey: Kashmira Kakati/WII 2002



Image 2. Deomali road passing through Jeypore Reserve Forest

Garo Hills <http://ifoundbutterflies.org/188-dodona/ dodona-longicaudata>. The species was first described in 1881 from Shillong, Khasia Hills by De Nicéville. A single female individual was sighted at Gaspani, Naga



Image 3. A small trail inside Jeypore Reserve Forest

Hills, at $455 \mathrm{~m}$. A male was collected from Cachar Road, Manipur in December and a female from the same place in November (Tytler 1915). The species is treated as very rare in Evans 1932. The species is so far known only 
from the south bank of the Brahmaputa and Patkai Hills of northeastern India.

Burmese Bushblue Arhopala birmana birmana Moore (Image 5): The species was encountered four times in JRF in January and February. The species has been recorded at Sebong, Manipur (Tytler 1915). The species is treated as not rare and the distribution range is from Assam-Dawnas (Evans 1932). The species is known only from the south bank of the Brahmaputra River Basin of northeastern India. Many specimens were seen in JRF, most of them had the white patches. The specimen photographed lack white patches. The species was confirmed birmana on the basis of upper side wing, border being $4 \mathrm{~mm}$ at apex, $2 \mathrm{~mm}$ in dorsum and $2.5 \mathrm{~mm}$ in hindwing (Evans 1957).

Blue Quaker Pithecops fulgens Doherty (Image 6,7): One individual was encountered at Tipam of JRF. The species was first described by Mr. Doherty from Margherita, Upper Assam. Since then, the species was collected in fairly good numbers from Irang and Lengba rivers, western Manipur hills (Tytler 1915). The species is rare as per Evans (1932). The species is similar to Forest Quaker, P. corvus from underside but differs from it as the upper side is blue with a brown border in males whereas in the P.corvus the upper side is brown. Swinhoe (1912-1913) describes the habitat of the species from Margherita, upper Assam based on Doherty's record. The species probably occurs only in south of Brahmaputra River Basin in the Patkai Bum of northeastern India.

Hooked Oakblue Arhopala paramuta DeNicéville (Image 8): The species is not rare and occurs from Sikkim to Karens as per as Evans 1932. The species is rare in Manipur and has been collected from Imphal at low elevations (Tytler 1915). The species occurs from midelevation of the eastern Himalaya to the lowest altitude of northeastern India. The insect was common near Kothalguri of JRF. I personally encountered the species a few times at Panbari Forest, Kaziranga, Assam.

Indian Oakblue Arhopala atrax (= alemon, hewitsoni) (Image 9): A female individual was encountered in JRF. The species is reported from Bengal, Niligiris, Poona, Pachmarhi, Orissa, Murre, Mussorie, Simla, Kumaon, Nepal, Sikkim, Assam, Burma-Ataran (Evans 1957). I found the species very common in the Eastern Ghats. The species is not common in northeastern India.

Tytler's Dull Oakblue Arhopala ace arata Tytler (Image 10): Two individuals were recorded in Gulmari of JRF in the month of Janurary. Another individual was encountered on the border between DehingPatkai WLS. I place the species under it on the basis of Evan's description 'below dark brown, marking very wide and prominent outlined white'. The specimens I encountered were less prominently outlined white. A male from Lengba River, Western Manipur Hills, and two from Sebong, East Manipur Hills have been reported and described for the first time by Tytler in 1915. The species has been reported as very rare (Evans 1932). The subspecies has so far been reported from Manipur and Ruby Mines, northern Burma (Evans 1957). Another subspecies occurs in Perak, Sumatra and Borneo.

Green Oakblue Arhopala eumolphus eumolphus Crammer (Image 11,12): One male and a few females were encountered in JRF during the field study. This subspecies is distributed in Sikkim, Nepal, Assam and is not rare as per Evans (1932).

Sylhet Oakblue Arhopala silhetensis silhetensis Hewtson (Image 13): One individual was encountered in September 2011 and appears to be smaller than the one I encountered at Panbari Forest. The race is distributed from Sikkim to northern Burma and is rare (Evans 1932). The species is protected under Schedule 2 of the Wildlife (Protection) Act, 1972.

Saffron Mota massyla Hewitson (Image 14): The species was sighted four times in JRF. The species was sighted from February-April. The species has been recorded from Sebong and on the Irang River in Manipur at low elevations and from Kirbari in Naga Hills at a higher elevation (Tytler 1915). The species is distributed from Bhutan-Burma and is rare (Evans 1932). The species has been reported to be locally common (Kehimkar 2008).

Narrow Spark Sinthusa nasaka amba Kirby (Image 15): One individual was recorded in September. The subspecies is distributed from Sikkim-Burma and is reportedly rare as per Evans 1932.

Branded Yamfly Yasoda tripunctata tripunctata Hewitson (Image 16): The species was encountered four times during my study in JRF. The species is rare as per Evans 1932. The species is protected under Schedule 2 of the Wildlife (Protection) Act, 1972.

Grey Baron Euthalia anosia anosia Moore (Image 17): One individual was encountered in Deomali road and another was sighted near Namsai tea estate in JRF in the month of November. It is a rare butterfly and habitat is from Sikkim-Burma.

Kohinoor Amathuxidia amythaon amythaon Doubleday (Image 18): One female and a male were sighted near Kothalguri of JRF in November. The male was found visiting bird droppings in a forest trail. After the male was recorded, the nearby forest patches were surveyed and the female was found subsequently. It is a large butterfly with a wing span of $110-130 \mathrm{~mm}$. It occurs 


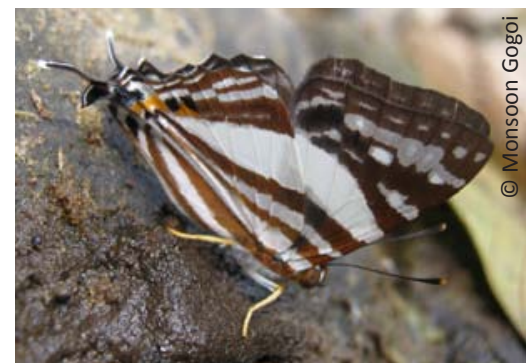

Image 4. Dodona longicaudato



Image 7. Pithecops fulgens (upper side)

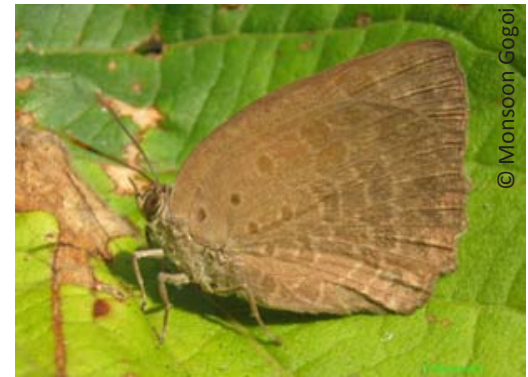

Image 10. Arhopala ace arata

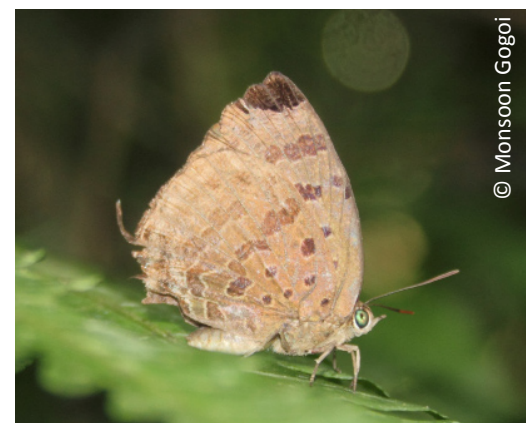

Image 13. Arhopala silhetensis



Image 5. Arhopala birmana



Image 8. Arhopala paramuta

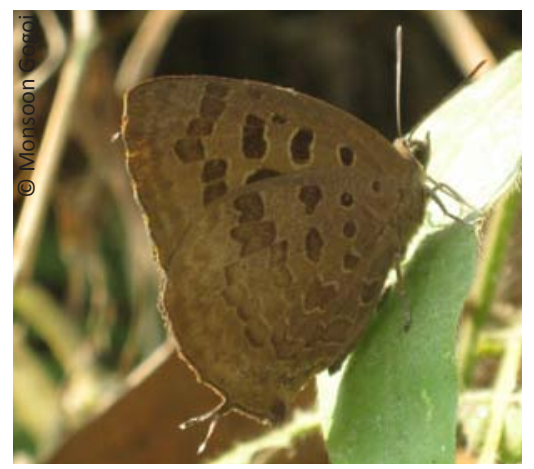

Image 11. Arhopala eumolphus eumolphus

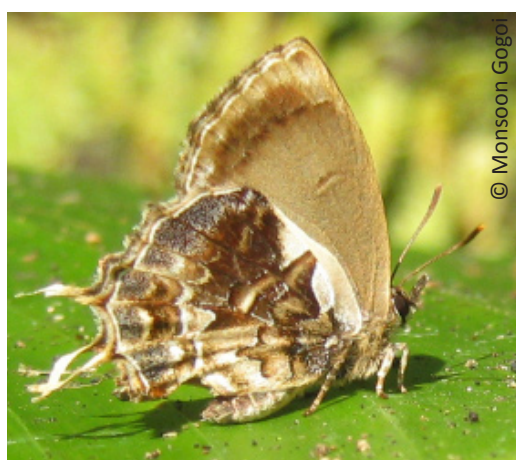

Image 14. Mota massyla

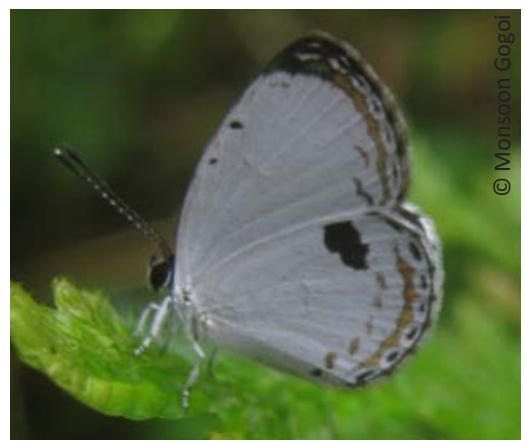

Image 6. Pithecops fulgens

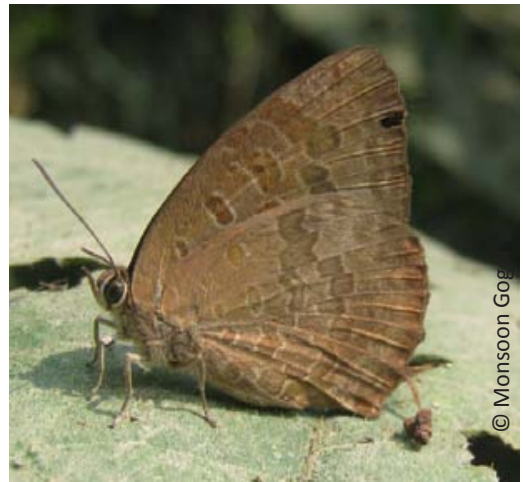

Image 9. Arhopala atrax female

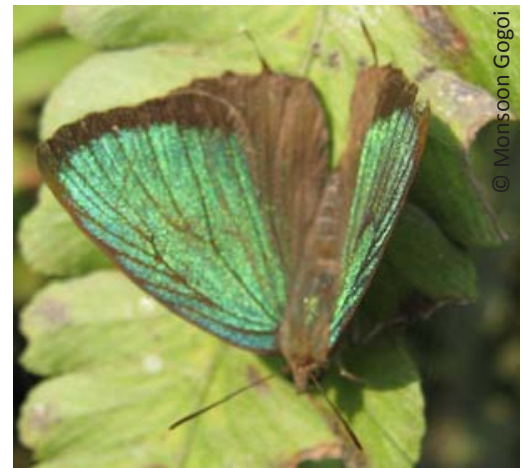

Image 12. Arhopala eumolphus eumolphus (upper side)



Image 15. Sinthusa nasaka amba 
in Sikkim-Arunachal Pradesh and in Bhutan, Bangladesh, and Myanmar. The species is rare in occurrence (Evans 1932).

Blue Nawab Polyura schreiber assamensis Rothschild (Image 19): One individual was encountered on Deomali road of JRF in November. The species was first seen mud-puddling with open wings. The species is very rare (Evans 1932). The subspecies was first described in the year 1899, type locality from (Khasi Hills, Jaintia Hills, Shillong, Cherra Punji) Meghalaya, Naga Hills, (Jorehat) Upper Assam and northern Burma (Myanmar). The butterfly also occurs in southern India as subspecies wardi Moore (1895).

Watson's Bushbrown Mycalesis adamsoni Watson (Image 20): Many individuals were encountered at the end of October 2010 and 2011. The species is rare and occurs in Manipur and northern Myanmar (Evans 1932). The ID key of the species is that the origin of $v 7$ is pushed back before end cell on hindwing.

Lilacine Bushbrown Mycalesis francisca sanatana Moore (Image 21): One individual was encountered in October, 2011. The species is not rare and occurs from Kulu-Burma (Evans 1932). However, the habitat of the species is from Sikkim-Burma (Talbot 1947). The v7 origin is at end cell of hind wing which differentiates the species from M. adamsoni.

Large Three-ring Ypthima nareda sarcaposa Fruhstorfer (Image 22): This subspecies is smaller in size in comparison to the other subspecies newara of northeastern India. The species has its distribution from Assam to Shan states and is not rare (Talbot 1947).

Striped Ringlet Ragadia crisilda crito De Nicéville (Image 23): The species was sighted twice in JRF. The taxon crito is distributed from Bhutan to Naga Hills and Manipur; rare (Talbot 1947). The subspecies crisilda occurs in Cachar, Assam.

Peal's Palmfly Elymnias pealii Wood-Mason (Image 24): The species was sighted about 10 times during the field study at different sites of JRF. The species is very rare and endemic to Assam (Evans 1932). The species is locally not rare but probably as it is restricted to Greater Assam, Evans treated it as very rare.

Dot-dash SergeantAthyma kanwa phorkys Fruhstorfer (Image 25): The species was encountered three times during the course of the field study in JRF. The species was found locally common in Assam. The species is rare and distributed in Assam-Burma (Evans 1932).

Spotted Sailer Neptis magadha khasiana Moore (Image 26): The species was found mud-puddling on a few occasions on the road to Deomali near Tipam of JRF in October. The race is distributed from Bhutan to northern Burma and is rare (Evans 1932).

Plain Sailer Neptis cartica cartica Moore (Image 27): One individual was encountered at Tipam in the month of October. The species was slightly smaller than the specimens I encountered in Mishmi Hills. Another subspecies, Neptis cartica burmana also occurs in Assam. I recorded this subspecies once in Dollamora and Panbari Forest (Kaziranga-Karbi Anglong) in 2009.

Perak Lascar Pantoporia paraka paraka Butler (Image 28): One individual was encountered puddling on a stone in a small nallah during March. The race is distributed from Assam to Myanmar, Thailand, Laos, Cambodia, Vietnam, Hainan, Malay Peninsular, Sumatra, Borneo, Banka, Batu, Java, Palawan. Another species Pantoporia assamica Moore (Assam-northern Bhutan) was also recorded in JRF (Image 29). The species is a race of Pantoporoa paraka in Global Lepidoptera Names Index (<http://www.nhm.ac.uk/research-curation/research/ projects/lepindex/>).

Extra Lascar Pantoporia sandaka davidsoni Eliot (Image 30): One individual was encountered during March, sitting upon a leaf near a small forest stream. The species was first described in 1892 from Borneo. The race davidsoni occurs from India to Myanmar, Thailand, Laos, Cambodia, Vietnam, Hainan and was named by Eliot in 1969 with type specimen from North Kanara, southern India.

Indian Awlking Choaspes benjaminii benjaminii Guerin-Meneville (Image 31): The species was common at Tipam nallah of JRF. The species could be found making rapid flight on Deomali road. The species is not rare and distribution is Sri Lanka and southern India (Evans 1932). The species was represented in Kulu, Karens, China, Siam as subspecies xanthropogon. However, the taxon xanthropogon was later validated as a different species and was considered synonymous to taxon similis. The taxon benjaminii is actually distributed all over India.

Similar Awlking Choaspes similis Evans (=xanthropogon) (Image 32): One individual was encountered in October. The species is distributed in Kashmir, Nepal, Sikkim, Assam, Myanmar, Thailand, Laos, Vietnam, China, Formosa. The species can be differentiated from $C$. stigmata from the underside in having tornal area not above V3, while in C. stigmata the tornal orange area continues above v3. In C. benjaminii the tornal orange area does not even reach V3. Also, the upper side base of $C$. stigmata is dark iridescent green but the upper side colour is uniform in $C$. similis.

Pale Striped Dawnfly Capilia zennara Moore (Image 33, 34): The species could be recorded a few times between Kothalguri and Tipam of JRF in November. One 




Image 16. Yasoda tripunctata

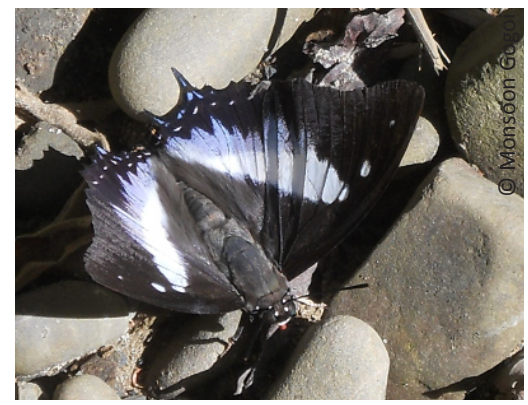

Image 19. Polyura schreiber assamensis

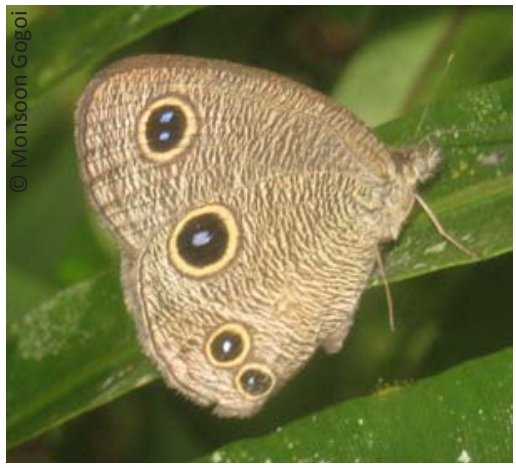

Image 22. Ypthima nareda sarcaposa



Image 25. Athyma kanwa

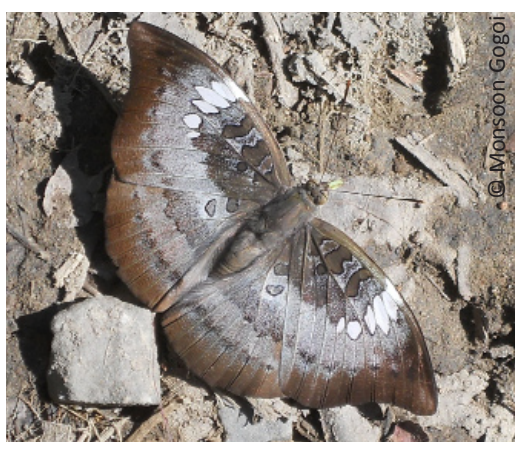

Image 17. Euthalia anosia anosia



Image 20. Mycalesis adamsoni



Image 23. Ragadia crisilda crito



Image 26. Neptis magadha khasiana



Image 18. Amathuxidia amythaon



Image 21. Mycalesis francisca sanatana

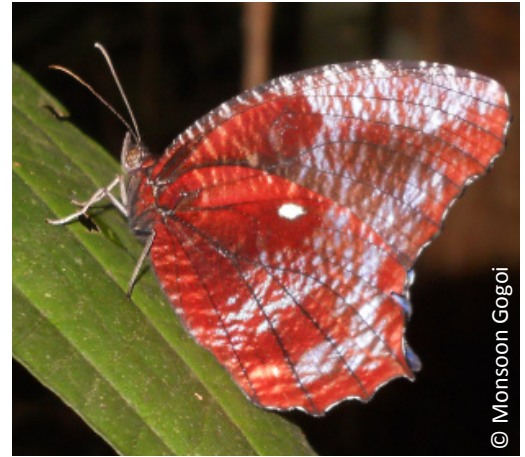

Image 24. Elymnias peali

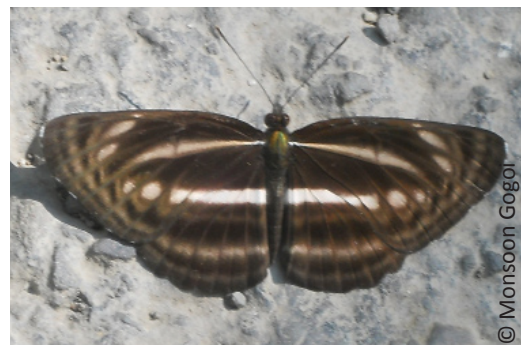

Image 27. Neptis cartica cartica 
male at Kothalguri road, and another just near it were recorded. Another male was found in the hill stream near Kothalguri. One female at Kothalguri, another at Tipam were recorded. The species has been reported from Nichuguard, Naga hills and Sebong, Naga hills (Tytler 1915). The species has been reported from Sikkim, Assam in India and occurs till Thailand. The species is treated very rare (Evans 1932). In recent times it has only been sighted from Buxa Tiger Reserve (Vivek Sarkar pers. comm. 2010) and Nambor RF, Karbi Anglong, upper Assam (Gaurab Nandi Das pers. comm. 2012).

Andaman Yellow-banded Flat Celaenorrhinus andamanicus hanna Evans (Image 35): The subspecies hanna was described by Evans in 1949 from Bhutan. Later it was also recorded from Thailand. The species was photographed in Kothalguri of JRF. This is a new addition to the butterfly fauna of mainland India. The key character of the species andamanicus mentioned by Evans (1932) is that the discal spot in $1 \mathrm{~b}$ is directed exactly to tornus.

Dusky Yellow-breast Flat Gerosis phisara phisara Moore (Image 36): A few male individuals were encountered in a river stream at Tipam of JRF. The subspecies is distributed from Sikkim to Burma and further up to Malaya and not rare (Evans 1932). The species is quite common in Assam.

White Yellow-breast Flat Gerosis sinica indica Evans (Image 37): One individual was encountered at Tipam at JRF. The subspecies occurs in Assam, another subspecies narada is found in Sikkim and subspecies sinica is distributed in central and western China and not rare (Evans 1932). The species is rare in Assam.

Sikkim White Flat Seseria sambara Moore (Image 38, 39): One individual was encountered in April and few times in October. The species does not appear common in the Naga Hills and Manipur (Tytler 1915).

Grass Bob Suada swerga swerga De Nicéville (Image 40): One individual was encountered in October. The species is not rare and the distribution range of the species is from Sikkim-Burma and further up to Malaya, Sumatra (Evans 1932). The species was first described in 1883 from Sikkim. The species is reported common at Sebong, Manipur during cold winters (Tytler 1915).

Malay Forest Bob Scobura phiditia Hewitson (=martini Elwes and Edwards) (Image 41, 42): The species has been mentioned by Tytler (1915) from Manipur as 'Scobura martini'. The species has been reported from Manipur to Burma, Malay Peninsula, Sumatra, Borneo and not rare (Evans 1932). The species has been recently sighted in Panbari Forest, Kaziranga, Assam by the author in 2010 (unpublished information of the author in 2001).
Interestingly on the individual recorded at JRF, there was no discal row of black spots on the underside hind wing (Evans description that often a discal row of black spots occurs). It looks a different race from those in the Panbari Forest of Kaziranga.

Large Forest Bob Scobura cephaloides cephaloides De Nicéville (Image 43): One individual was encountered near Dilli River. I have recorded the species from Mishmi Hills and Panbari Forest, Assam. The species has been recorded from Naga Hills and Western Manipur Hills (Tytler 1915). The species is rare and distributed from Sikkim - souther Shan States, Tonkin and Hainan (Evans 1932).

Dark-branded Swift Caltoris brunnea Snellen (Image 44, 45): One individual was encountered in October. The species has a wide range of distribution from Sikkim-Bhutan and further up to Borneo and is not rare (Evans 1932). The species was first described in 1876, type locality is Java. The species could be identified by a narrow grey brand mid-vein 1 to lower inner edge of spot 2 in the male.

Tufted Swift Caltoris plebeia DeNicéville (Image 46): A male specimen was sighted at JRF, in February near Dehing-Patkai WS. The species is distributed from Sikkim to Bhutan and further up to Java, Borneo and Pulo Laut (Evans 1932).

Atkinson's Bob Arnetta atkinsoni Moore (Image 47): Four individuals were recorded in Gulmari of JRF. The species is not rare as per Evans 1932. The species is distributed from Sikkim to Tavoy and is not rare (Evans 1932).

Halpe homolea homolea Hewitson (Image 48): The species was common in JRF. The Halpe species has a brand on the upper wing. The species seems to fit Halpe homolea homolea as spots are present on the small upper side and on the underside sub marginal and discal spots are clearly defined. Tytler (1915) mentioned the species to be very common in Manipur and Naga Hills. Evans (1932) described the species as not rare.

Yellow-vein Lancer Pyroneura margherita Doherty (Images 49, 50): The species was encountered four times near Kothalguri in JRF in summer. The species has been treated as a subspecies of latoia with locality from Upper Assam and Tenasserim and very rare (Evans 1932). But, the species is not rare in upper Assam. I encountered the species many times in Panbari Forest of Kaziranga. But, the specimens of Jeypore differ from that of Panbari in having conjoined cell spots in the forewing, while in the latter the cell spots are separate.

Northern Spotted Ace Thoressa cerata Hewitson (Images 51,52): The species was encountered many times 




Image 28. Pantoporia paraka paraka

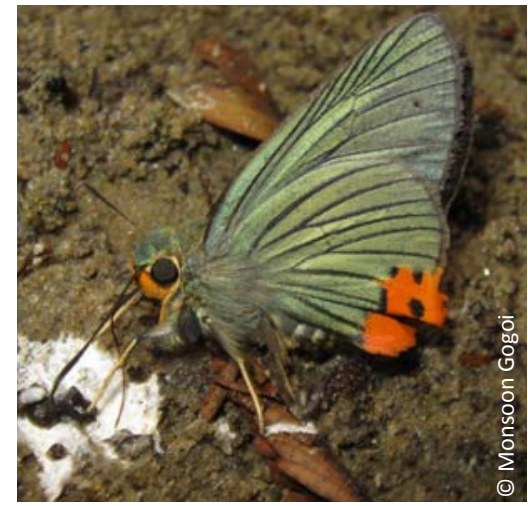

Image 31. Choaspes benjamini

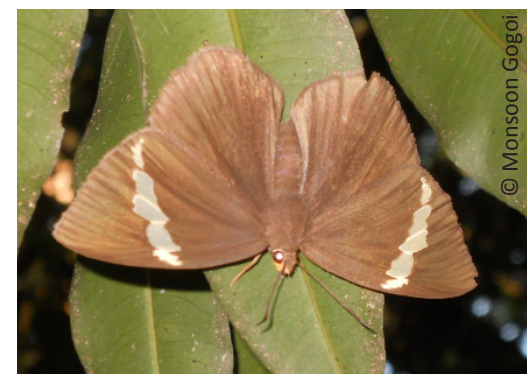

Image 34. Capilia zennara (female)



Image 37. Gerosis sinica indica



Image 29. Pantoporia assamica (race of paraka?)

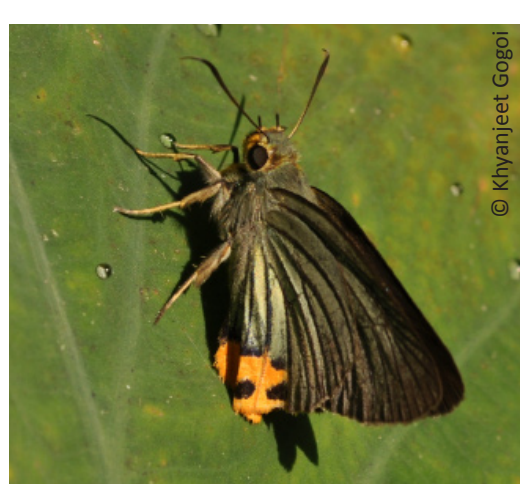

Image 32. Choaspes similis

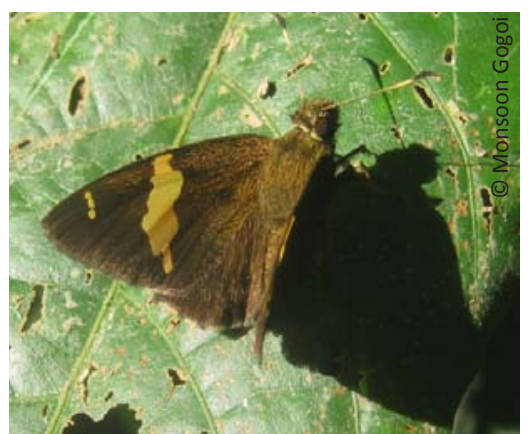

Image 35. Celaenorrhinus andamanicus hanna

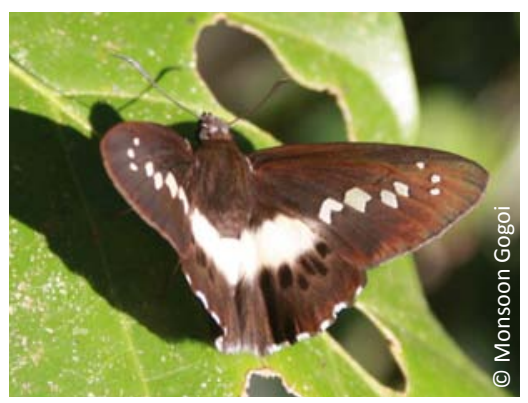

Image 38. Seseria sambara (upper side)

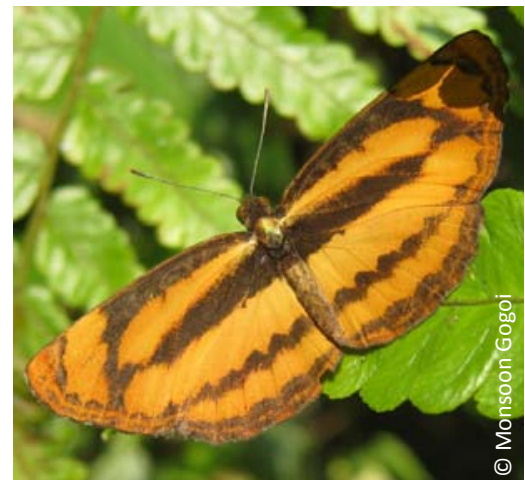

Image 30. Pantoporia sandaka davidsoni

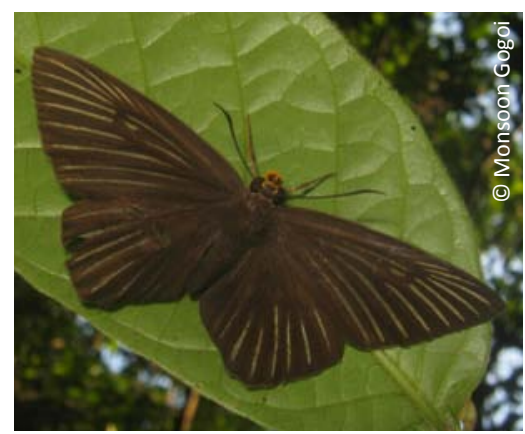

Image 33. Capilia zennara (male)



Image 36. Gerosis phisara phisara



Image 39. Seseria sambara (under side) 




Image 40. Suada swerga



Image 43. Scobura cephaloides cephaloides



Image 46. Caltoris plebeia



Image 49. Pyroneura margherita (upper side)

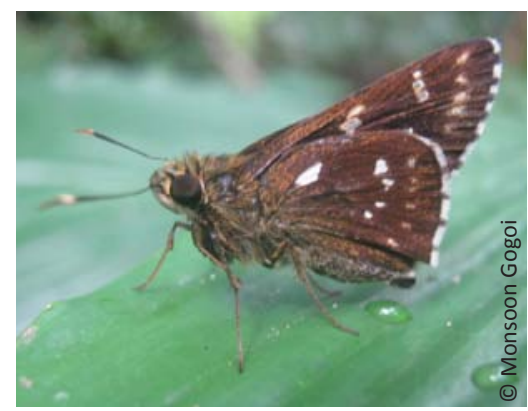

Image 52. Thoressa cerata



Image 41. Scobura phiditia=martini



Image 44. Caltoris brunnea

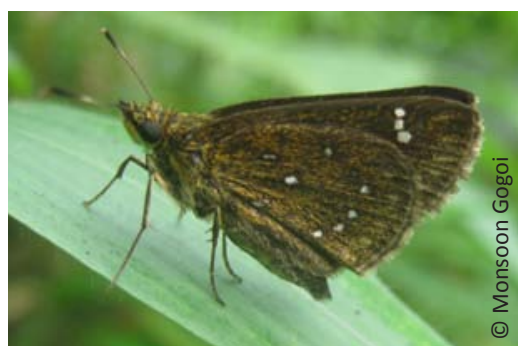

Image 47. Arnetta atkinsoni

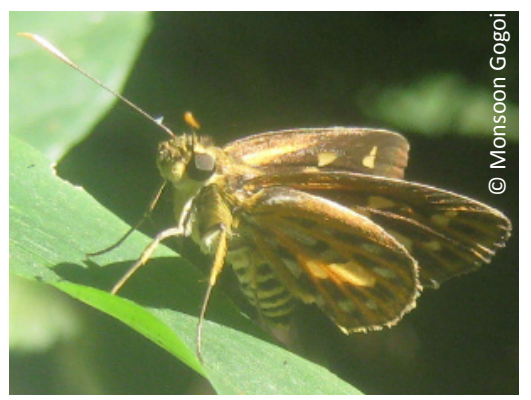

Image 50. Pyroneura margherita



Image 53. Asticopterus jama



Image 42. Scobura phidita=martini (upper side)



Image 45.Caltoris brunnea (upper side)



Image 48. Halpe homolea homolea

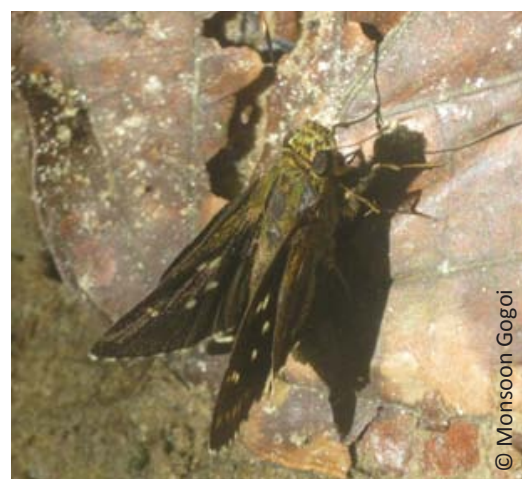

Image 51. Thoressa cerata (upper side)

Journal of Threatened Taxa | www.threatenedtaxa.org | 26 February 2013 | 5(2): 3684-3696 
in JRF. The specimens differ from the higher elevation races of Arunachal Pradesh (Mishmi Hills, Namdapha) in having very small discal and post-discal spots in the underside of hindwing. The specimens of Panbari also had very small spots. The species is distributed from Sikkim to Karens and is not rare (Evans 1932).

Forest Hopper Asticopterus jama olivascens Moore (Image 53): One individual was encountered at Gulmari in JRF. The race is distributed from Kumaon to Karens, Siam and not rare (Evans 1932).

\section{Discussions}

During the survey many significant butterflies were sighted from the lowland forests of JRF. February and November were found to be best months for butterflies in JRF. Altogether, a total of 292 species of butterflies were recorded as a result of continuous field surveys conducted during 2010-2011 which included two sightings Darpa pteria (Karthikeyan \& Venkatesh 2011) and Chersonesia rahira rahrioides (Vidya Venkatesh \& S. Karthikeyan pers. comm. 2011) (Table 1). There are many factors influencing the species richness of JRF. The average elevation of JRF of about $150 \mathrm{~m}$, lying in the foothills of the Patkai range of northeastern India, influences the distribution pattern of butterflies. A few of the butterflies of JRF show interesting bio-geographic pattern due to the barrier effect of the Brahmaputra River Basin (BRB). As JRF lies on the South Bank of BRB species such as Pithecops fulgens, Dodona longicaudata, Arhopala birmana, Pyroneura margherita occur in JRF. These species were not known from the north bank of the Brahmaputra River Basin as it acts as a barrier of species distribution. Further, JRF is also classified as a rainforest due to its unique precipitation which might be another factor contributing to species richness in the area. Overall, sighting of extremely rare species such as Dodona longicaudata, Capilia zennara, Amathuxidia amythaon, Pithecops fulgens etc. shows the importance of saving the last remaining lowland forests in Assam and northeastern India.

\section{REFERENCES}

Champion H.G. \& S.K. Seth (1968). A Revised Survey of the Forest Types of India. The Manager of Publications, Government of India, New Delhi, 404pp.

Evans, W.H. (1932). The Identification of Indian Butterflies-2nd Edition. Bombay Natural History Society, Mumbai, India, 464pp.

Evans, W.H. (1957). A revision of the Arhopala group of oriental Lycaenidae (Lepidoptera: Rhopalocera). Bulletin of British Museum (Natural History) Entomology 5(3): 85-141.

Haribal, M. (1992).The Butterflies of Sikkim Himalaya. Sikkim Nature Conservation Foundation, Sikkim, India. 217pp.
Table 1. Checklist of butterflies of Jeypore-Dehing Reserve Forest recorded by the author during February 2010-October 2011. The checklist includes sighting of two species-Snowy Angle Darpa pteria (S. Karthikeyan \& V. Venkatesh 2011) and Wavy Maplet Chersonesia rahira rahrioides (Vidya Venkatesh \& S. Karthikeyan pers. comm. 2011).

\begin{tabular}{|c|c|c|}
\hline & Common Name & Scientific Name \\
\hline \multicolumn{3}{|c|}{ Papilionidae } \\
\hline 1 & Great Windmill & Byasa dasarada ravana \\
\hline 2 & Great Mormon & Papilio memnor agenor \\
\hline 3 & Common Mormon & Papilio polytes romulus \\
\hline 4 & Common Rose & Atrophaneura aristolochiae \\
\hline 5 & Redbreast & Papilio alcmenor \\
\hline 6 & White Dragontail & Leptocircus curius curius \\
\hline 7 & Red Helen & Papilio helenus helenus \\
\hline 8 & Yellow Helen & Papilio nephelus \\
\hline 9 & Common Ravern & Papilio castor castor \\
\hline 10 & Common Bluebottle & Graphium sarpedon sarpedon \\
\hline 11 & Common Jay & Graphium doson axion \\
\hline 12 & Great Jay & Graphium eurypylus acheron \\
\hline 13 & Five-bar Swordtail & Graphium antiphates pompilius \\
\hline 14 & Lesser Batwing & Parides aidoneus \\
\hline 15 & Common Batwing & Parides varuna astorion \\
\hline 16 & Spange & Papilio protenor euprotenor \\
\hline 17 & Common Birdwing & Triodes helena cerberus \\
\hline 18 & Paris Peacock & Papilio paris paris \\
\hline 19 & Common Peacock & Papilio polyctor ganesa \\
\hline 20 & Great Zebra & Graphium xenocles xenocles \\
\hline 21 & Great Blue Mime & Chilasa paradoxa telearchus \\
\hline \multicolumn{3}{|c|}{ Pieridae } \\
\hline 22 & Three Spot Grass Yellow & Eurema blanda silhetana \\
\hline 23 & Common Grass Yellow & Eurema hecabe contubernalis \\
\hline 24 & Tree Yellow & Gandaca harina assamica \\
\hline 25 & Tailed Sulphur & Dercus verhuelli doubeldayi \\
\hline 26 & Redbreast Jezabel & Delias thysbe pyramus \\
\hline 27 & Redbase Jezabel & Delias aglaia \\
\hline 28 & Common Emigrant & Catopsilia pomona (=crocale) \\
\hline 29 & Mottled Emigrant & Catopsilia pyranthe minna \\
\hline 30 & Yellow Orange Tip & Ixias pyrene satadra \\
\hline 31 & Great Orange Tip & Hebomia glaucippe glaucippe \\
\hline 32 & Pale Wanderer & Pareronia avatar avatar \\
\hline 33 & Greenvein White & Pieris napi montana \\
\hline 34 & Spot Puffin & Appias lalage lalage \\
\hline 35 & Chocolate Albatross & Appias lyncida hippoides \\
\hline 36 & Lesser Gull & Cepora nadina nadina \\
\hline 37 & Indian Cabbage White & Pieris canidiaindica \\
\hline 38 & Psyche & Leptosia nina nina \\
\hline
\end{tabular}




\begin{tabular}{|c|c|c|c|c|c|}
\hline & Common Name & Scientific Name & & Common Name & Scientific Name \\
\hline \multicolumn{3}{|c|}{ Nymphalidae } & 84 & Common Evening Brown & Melanitis leda ismene \\
\hline 39 & Chocolate Tiger & Parantica melaneus plateniston & 85 & Common Bushbrown & Mycalesis perseus blasius \\
\hline 40 & Chestnut Tiger & Parantica tytia sita & 86 & Dark-brand Bushbrown & Mycalesis mineus mineus \\
\hline 41 & Glassy Tiger & Parantica aglea melanoides & 87 & Long-brand Bushbrown & Mycalesis visala visala \\
\hline 42 & Dark Blue Tiger & Tellervo melissa septentrionis & 88 & Chinese Bushbrown & Mycalesis gotama charaka \\
\hline 43 & Striped Tiger & Danaus genutia=plexippus & 89 & Lilacine Bushbrown & Mycalesis francisca sanatana \\
\hline 44 & Plain Tiger & Danaus chrysippus & 90 & Watson's Bushbrown & Mycalesis adamsoni \\
\hline 45 & Common Faun & Faunis arecsilaus & 91 & Common Fivering & Ypthima baldus baldus \\
\hline 46 & Yellow Rajah & Charaxes marmax & 92 & Large Threering & Ypthima nareda sarcaposa \\
\hline 47 & Tawny Rajah & Charaxes polyxena hierax & 93 & Common Fourring & Ypthima hubneri huebneri \\
\hline 48 & Black Rajah & Charaxes fabius sulphureus & 94 & Striped Ringlet & Ragadia crisilda crito \\
\hline 49 & Variegated Rajah & Charaxes kahruba & 95 & Plain Bushbrown & Mycalesis malsarida \\
\hline 50 & Great Nawab & Polyura eudamippus & 96 & Dusky Diadem & Anadebis himachala \\
\hline 51 & Blue Nawab & Polyura schreiber assamensis & 97 & Autumn Leaf & Doleschallia bisaltide indica \\
\hline 52 & Pallid Nawab & Polyura arja & 98 & Red Caliph & Enispe euthymius \\
\hline 53 & Common Nawab & Polyura athamasathamas & 99 & Kohinoor & Amathuxidia amythaon \\
\hline 54 & Short-banded Sailer & Phaedyma columella ophiana & 100 & Jungle Glory & Thaumantis diores \\
\hline 55 & Common Sailer & Neptis hylas adara & 101 & Orange Oakleaf & Kallima inachus \\
\hline 56 & Rich Sailer & Neptis anjana nasnah & 102 & Courtesian & Euripus halitherses \\
\hline 57 & Dingrest Sailer & Neptis harita & 103 & Circe & Hestina nama \\
\hline 58 & Small Yellow Sailer & Neptis miah & 104 & Common Map & Cyrestis thyodamas indica \\
\hline 59 & Yellow Sailer & Neptis namba & 105 & Constable & Dichorragia nesimachus \\
\hline 60 & Sullied Sailer & Neptis soma soma & 106 & Crusier & Vindula erota erota \\
\hline 61 & Clear Sailer & Neptis nandina susruta & 107 & Great Arkduke & Adolias cyanipardus \\
\hline 62 & Spotted Sailer & Neptis magadha khasiana & 108 & Magpie Crow & Euploea diocletiana ramsayi \\
\hline 63 & Yerbury's Sailer & Neptis yerburyi sikkima & 109 & Striped Blue Crow & Euploea mulciber mulciber \\
\hline 64 & Plain Sailer & Neptis cartica cartica & 110 & Great Eggfly & Hypolimnas bolina \\
\hline 65 & Common Lascar & Pantoporia hordon & 111 & Common Earl & Tanaecia julii sedeva \\
\hline 66 & Exra Lascar & Pantoporia sandaka & 112 & Plain Earl & Tanaecia jahnu jahnu \\
\hline 67 & Perak Lascar & Pantoporia peraka & 113 & Common Baron & Euthalia aconthia garuda \\
\hline 68 & Greylined Lascar & Pantoporia dindinga assamica & 114 & Grey Baron & Euthalia anosia anosia \\
\hline 69 & Common Sergent & Athyma perius & 115 & Gaudy Baron & Euthalia lubentina indica \\
\hline 70 & Colour Sergent & Athyma nefte inara & 116 & White-edge Blue Baron & Euthalai phemius \\
\hline 71 & Black-veined Sergent & Athyma ranga ranga & 117 & Powdered Baron & Euthalia monina kesava \\
\hline 72 & Staff Sergent & Athyma selenophora selenophora & 118 & Blue Baron & Euthalia telchinia \\
\hline 73 & Small Staff Sergent & Athyma zeroca & 119 & Streaked Baron & Euthalia alpheda jama \\
\hline 74 & Orange Staff Sergent & Athyma cama & 120 & Chocolate Pansy & Junonia iphita \\
\hline 75 & Unbroken Sergent & Athyma pravara acutipennis & 121 & Peacock Pansy & Junonia almana \\
\hline 76 & Dot-Dash Sergent & Athyma kanwa phorkys & 122 & Grey Pansy & Junonia atlites \\
\hline 77 & Common Jester & Symbrenthia hippoclus khasiana & 123 & Lemon Pansy & Junonia lemonias \\
\hline 78 & Banded Treebrown & Lethe confusa gambara & 124 & Blue Pansy & Junonia orythiya \\
\hline 79 & Tailed Red Forester & Lethe sinorix & 125 & Yellow Pansy & Junonia hierita \\
\hline 80 & Common Red Forester & Lethe mekara zuchara & 126 & Red Lacewing & Cethosia biblis tisamena \\
\hline 81 & Black Forester & Lethe vindhya & 127 & Leopard Lacewing & Cethosia cyane \\
\hline 82 & Pallid Forester & Lethe satyavati & 128 & Green Commodore & Limenitis daraxa \\
\hline 83 & Great Evening Brown & Melanitis zitenius zitenius & 129 & Blue Admiral & Kaniska canace \\
\hline
\end{tabular}




\begin{tabular}{|c|c|c|c|c|c|}
\hline & Common Name & Scientific Name & & Common Name & Scientific Name \\
\hline 130 & Maplet & Chersonesia risa & 175 & Green Oakblue & Arhopala emolphus emolphus \\
\hline 131 & Wavy Maplet & Chersonesia rahira rahrioides & 176 & Indian Oakblue & Arhopala atrax \\
\hline 132 & Indian Fritillary & Argyreus hyperbius & 177 & Sylhet Oakblue & Arhopala sylhetensis \\
\hline 133 & Common Leopard & Phalanta phalantha & 178 & Centaur Oakblue & Arhopala pseudocentaurus \\
\hline 134 & Common Castor & Ariadne merione assama & 179 & Hooked Oakblue & Arhopala paramuta \\
\hline 135 & Angled Castor & Ariadne ariadne & 180 & Tytler's Dull Oakblue & Arhopala ace arata \\
\hline 136 & Commander & Moduza procris & 181 & Burmese Bushblue & Arhopala birmana \\
\hline 137 & Large Yeoman & Cirrochroa aoris & 182 & Pale Bushblue & Arhopala aberrans \\
\hline 138 & Common Yeoman & Cirrochroa tyche & 183 & Variegated Plushblue & Flos adriana \\
\hline 139 & Vagrant & Vagrans egista & 184 & Metallic Cerulean & Jamides alecto \\
\hline 140 & Nigger & Orsotrioena medus & 185 & Common Cerulean & Jamides celeno \\
\hline 141 & Tiger Palmfly & Elymnias nesoea & 186 & Dark Cerulean & Jamides bochus \\
\hline 142 & Peal's Palmfly & Elymnias pealii & 187 & Common Imperial & Cheritra freja \\
\hline 143 & Common Palmfly & Elymnias hypermnestra & 188 & Blue Imperial & Ticherra acte \\
\hline 144 & Grey Count & Tanaecia lepidea & 189 & Common Tit & Hypolycaena erylus \\
\hline 145 & Wizard & Rhynopalpa polynice & 190 & Fluffy Tit & Zeltus etolus \\
\hline 146 & Knight & Lebade martha & 191 & Orchid Tit & Chliaria othona \\
\hline 147 & Yellow Coster & Acraea issoria & 192 & Narrow Spark & \\
\hline \multicolumn{3}{|c|}{ Lycaenidae } & 193 & Broad Spark & \\
\hline 148 & Common Gem & Poritia hewitsoni & 194 & Lime Blue & Chilades laius \\
\hline 149 & Common Hedge Blue & Acytolepis puspa & 195 & Pale Grass Blue & Zizeeria maha \\
\hline 150 & Metallic Hedge Blue & Lycaenopsis melaena parrishii & 196 & Dark Grass Blue & Zizeeria karsandra \\
\hline 151 & Margined Hedge Blue & Celastrina marginata & 197 & Lesser Grass Blue & Zizeeria otis \\
\hline 152 & White-banded Hedge Blue & Lycaenopsis transpecta & 198 & Common Pierot & Castalius rosimon \\
\hline 153 & Albocaerulean & Udara albocaerulea & 199 & Elbowed Pierrot & Pycnophallium elna \\
\hline 154 & Plain Hedge Blue & Cyaniris placida & 200 & Dark Pierrot & Tarucus ananda \\
\hline 155 & Pale Hedge Blue & Celastrina cardia & 201 & Copper Flash & Rapala rectivitta \\
\hline 156 & Jyntea Hedge Blue & Celastrina jynteana & 202 & Malay Red Flash & Rapala damona \\
\hline 157 & Swinhoe's Hedge Blue & Celastrina musinoides & 203 & Slate Flash & Rapala schistacea \\
\hline 158 & Hill Hedge Blue & Celasteina argiolus & 204 & Common Flash & Rapala rosacea \\
\hline 159 & Tiny Hedge Blue & Lycaenopsis minima & 205 & Saffron & Mota massyla \\
\hline 160 & Blue Quaker & Pithecops fulgens & 206 & Chocolate Royal & Remelana jangala ravata \\
\hline 161 & Quaker & Neopithecops zalmora & 207 & Bi-Spot Royal & Ancema ctesia \\
\hline 162 & Malayan & Megisba malaya sikkima & 208 & Long-banded Silverline & Spindasis lohita himalayanus \\
\hline 163 & Forget-me-not & Catochrysops strabo & 209 & Common Acacia Blue & $\begin{array}{l}\text { Surendra quercetorum } \\
\text { quercetorum }\end{array}$ \\
\hline 164 & Silver-forget-me-not & Catochrysops panormus & 210 & Purple Sapphire & Heliophorus epicles indicus \\
\hline 165 & Transparent 6 Lineblue & Nacaduba kurava & 211 & Peablue & Lampides boeticus \\
\hline 166 & Pale 4 Lineblue & Nacaduba hermus nabo & 212 & Zebra Blue & Syntarucus plinius \\
\hline 167 & Opaque 6 Lineblue & Nacaduba beroe gythion & 213 & Una & Una usta \\
\hline 168 & Common Lineblue & Prosotas nora & 214 & Angled Sunbeam & Curetis acuta \\
\hline 169 & Banded Lineblue & Prosotas aluta coelestis & 215 & Yamfly & Loxura atymnus \\
\hline 170 & Pointed Lineblue & Ionolyce helicon & 216 & Branded Yamfly & Yasoda tripunctata \\
\hline 171 & Tailless Lineblue & Prosotas duboisa indica & 217 & Tailed Judy & Abisara neophron \\
\hline 172 & Dingy Lineblue & Nacaduba dana & 218 & Dark Judy & Abisara fylla \\
\hline 173 & Common Ciliate Blue & Anthene emolus & 219 & Punchinello & Zemeros flegyas indicus \\
\hline 174 & Pointed Ciliate Blue & Anthene lycaenina & 220 & Plum Judy & Abisara echerius prunosa \\
\hline
\end{tabular}




\begin{tabular}{|c|c|c|}
\hline & Common Name & Scientific Name \\
\hline 221 & White Punch & Dodona henrici \\
\hline \multicolumn{3}{|c|}{ Hesperiidae } \\
\hline 222 & Orange-tail Awl & Bibasis sena \\
\hline 223 & Similar Awlking & Choaspes similis \\
\hline 224 & Indian Awlking & Choaspes benjaminii \\
\hline 225 & Brown Awl & Badamia exclamationis \\
\hline 226 & Common Awl & Hasora badra \\
\hline 227 & White-banded Awl & Hasora taminatus \\
\hline 228 & Branded Orange Awlet & Bibasis oedipodea aegina \\
\hline 229 & Common Snow Flat & Tagiades japetus ravi \\
\hline 230 & Suffused Snow Flat & Tagiades gana \\
\hline 231 & Dusky Yellow-breast Flat & Gerosis phisara \\
\hline 232 & White Yellow-breast Flat & Gerosis sinica indica \\
\hline 233 & Brown Pied Flat & Coladenia agni \\
\hline 234 & Pale Striped Dawnfly & Capilia zennara \\
\hline 235 & & Celaenorrhinus putra(=leucocera?) \\
\hline 236 & & Celaenorrhunis nigricans \\
\hline 237 & Dark-yellow banded Flat & Celaenorrhinus aurivittata \\
\hline 238 & $\begin{array}{l}\text { Andaman Yellowbanded } \\
\text { Flat }\end{array}$ & $\begin{array}{l}\text { Celaenorrhinus andamanicus } \\
\text { hanna }\end{array}$ \\
\hline 239 & Sikkim White Flat & Seseria sambara \\
\hline 240 & Water Snow Flat & Tagiades litigiosa \\
\hline 241 & Fulvous Pied Flat & Pseudocoladenia dan \\
\hline 242 & Chestnut Angle & Odontoptilum angulata \\
\hline 243 & Snowy Angle & Darpa pteria \\
\hline 244 & Common Small Flat & Sarangesa dasahara \\
\hline 245 & Indian Skipper & Spialia galba \\
\hline 246 & Pygmy Scrub Hopper & Aeromachus pygmaeus \\
\hline 247 & Veined Scrub Hopper & Aeromachus stigmata obsoleta \\
\hline 248 & Bush Hopper & Ampittia dioscorides \\
\hline 249 & Tiger Hopper & Ochus subvittatus \\
\hline 250 & Forest Hopper & Asticopterus jama \\
\hline 251 & Palm Redeye & Erionota thrax \\
\hline 252 & Fringed Red Eye & Matapa cresta \\
\hline 253 & Common Redeye & Matapa aria \\
\hline 254 & Yellow-vein Lancer & Pyroneura margherita \\
\hline 255 & Light Straw Ace & Pithauria stramineipennis \\
\hline 256 & Northern Spotted Ace & Thoressa cerata \\
\hline 257 & Sikkim Ace & Halpe sikkima \\
\hline 258 & Plain Ace & Halpe kumara \\
\hline 259 & Indian Ace & Halpe homolea \\
\hline 260 & Hill Ace & Halpe kusala \\
\hline 261 & Banded Ace & Halpe zema \\
\hline 262 & Tufted Ace & Sebastonyma dolopia \\
\hline 263 & Common Banded Demon & Notocrypta paralysos \\
\hline 264 & Restricted Demon & Notocrypta curvifascia \\
\hline
\end{tabular}

\begin{tabular}{|c|c|c|}
\hline & Common Name & Scientific Name \\
\hline 265 & Chocolate Demon & Ancistroides nigrita \\
\hline 266 & Grass Demon & Udaspes folus \\
\hline 267 & Dark Velvet Bob & Koruthaialos butleri \\
\hline 268 & Chestnut Bob & lambrix sasala \\
\hline 269 & Grass Bob & Suada swerga \\
\hline 270 & Khasi Forest Bob & Scobura isota \\
\hline 271 & Large Forest Bob & Scobura cephaloides \\
\hline 272 & Malay Forest Bob & Scobura phidita \\
\hline 273 & Atkinson's Bob & Arnetta atkinsoni \\
\hline 274 & Wax Dart & Cupitha purreea purreea \\
\hline 275 & Common Dartlet & Oriens gola \\
\hline 276 & Common Dart & Potanthus pseudomaesa clio \\
\hline 277 & Sumatran Dart & Potanthus ganda \\
\hline 278 & Common Palm Dart & Telicota colon \\
\hline 279 & Plain Palm Dart & Cephrenes acalle \\
\hline 280 & Paintbrush Swift & Baoris penicillata unicolor \\
\hline 281 & Paintbrush Swift & Baoris farri \\
\hline 282 & Blank Swift & Caltoris kumara \\
\hline 283 & Figure of 8 Swift & Caltoris pagana \\
\hline 284 & Full-stop Swift & Caltoris cormasa moolata \\
\hline 285 & Colon Swift & Caltoris cara \\
\hline 286 & Great Swift & Pelopidas assamensis \\
\hline 287 & Tufted Swift & Caltoris plebeia \\
\hline 288 & Dark-branded Swift & Caltoris brunnea \\
\hline 289 & Large Branded Swift & Pelopidas sinensis \\
\hline 290 & Small Branded Swift & Pelopidas mathias \\
\hline 291 & Straight Swift & Parnara bada \\
\hline 292 & Bevan's Swift & Pseudoborbo bevani \\
\hline
\end{tabular}

Karthikeyan, S. \& V. Venkatesh (2011). "Snowy Angle Darpa pteria". The Wild Wanderer, 07 September 2011 (Retrieved on 10 February 2012 from http://www.wildwanderer.com/journal/?p=435).

Kehimkar, I. (2008). The Book of Indian Butterflies. Bombay Natural History Society and Oxford University Press, Mumbai, India, 497pp.

Swinhoe, C. (1912-1913). Lepidoptera Indica. Part X. RhopaloceraHesperiidae. Lovell, Reeve \& Co. Ltd., London, 364pp+757-835pls.

Talbot, G. (1947). The Fauna of British India, including Ceylon and Burma: Butterflies - Vol. II. Taylor and Francis, London, 506pp.

Tytler, H.C. (1915). Notes on some new and interesting butterflies from Manipur and the Naga Hills. Journal of the Bombay Natural History Society 23: $502-515+4$ pls. 